\title{
SHOULD THE FEDERAL INCOME TAX BE SIMPLIFIED?
}

\author{
BY ROBERT B. EICHHOLZ $\dagger$
}

NewSPAPER editorial writers, columnists and cartoonists reserve some of their choicest phrases for the spectacle of the harassed taxpayer in his annual struggle to comply with the demands of the federal tax collector. It is not unjustifiably felt that the pains of paying taxes should not be rendered too protracted and excruciating by keeping the victim ignor'ant of how to pay. The universally recommended anesthetic is "simplifica" tion." It has come to be regarded as axiomatic that the federal tax laws in general and the income tax in particular should be made less complicated, and that we should strive for both a simple tax law and a tax law simply stated. During last year's widespread public discussion of possible changes in the federal tax structure, scarcely an article was written or a suggestion made that did not at some point enter a plea for simplicity. It is assumed on every hand that simplification will result in a fairer statute, in greater ease of administration and in a reduction of the expense and irritation that often accompany the proper computation of a taxpayer's liability. The argument for simplicity is usually considered so obvious as not to require further statement. When the question is examined, however, the suspicion arises that the last thing the taxpayer would really want is this almost universally recommended cure-all for our tax troubles.

The American ancestors of the income tax were very simple levies. In Colonial New England and other American colonies, there existed various "faculty" taxes upon the yearly earnings from certain employments, assessed by classes. ${ }^{1}$ Having as much in common with the property taxes which they supplemented as with the modern income tax, they were levied not upon the taxpayer's actual earnings, but upon the earnings which he was assumed to derive from the occupation in which he engaged.

Secretary of the Treasury Wolcott, in his report of 1796 , had this to say about the faculty taxes:

"In some states those taxes are attempted to be proportioned to the gains and profits of individuals, in which cases they are both arbitrary and unequal; in other states the taxes are uniform, in which cases they are only unequal . . .

† Member of Legislative Counsel's staff, United States Treasury Department. A1though the writer is employed by the Treasury Department, the views set forth herein are his own and are not to be regarded as the views of the Department. The present article is a revision of material presented before the New York City Chapter of the National Lawyers' Guild, April 7, 1938.

1. See E. R. A. Seligman, Tae Income Tax (2d ed. 1914) 367. 
"It is impossible to render them exactly equal; that they are easy of collection, that their operation is indirect, and that they are capable of being rendered perfectly certain, are recommendations in their favor." 2

The first effective federal attempt at an income tax was the Civil War Act of $1862 .^{3}$ It comprised only eight sections and came near to taxing gross income. It subjected to tax income "from any source whatever" and allowed only a deduction for taxes "assessed upon the property from which the income is derived." At that time even the Commissioner of Internal Revenue was moved to remark that the income tax was "deprived . . . of all claims to public favor," largely because of its "inquisitorial" character. ${ }^{4} \mathrm{He}$ regarded as worthy of comment the forbearance of taxpayers in accepting it "to meet a temporary exigency." The law was slowly improved upon, and by $1870^{\circ}$ had attained to some approximation of a concept of net income ${ }^{6}$ through the allowance of a few additional deductions. In the process of rendering them more palatable, the original eight sections had increased to twelve.

The Act of $1894,{ }^{7}$ which Mr. Choate so dramatically denounced as "communistic" and, climactically, as "populistic," allowed deductions for interest, business and farming expenses, taxes, losses from fires, storms and shipwreck, and bad debts. By the 1913 Act $^{9}$ seventeen pages were needed to write an income tax law, though that document hardly seems formidable when compared with the more than one hundred and forty pages which were required for the Revenue Act of $1938 .^{10}$

Thus in sheer bulk the income tax act has grown with fearsome rapidity. In the space of 25 years its length has increased approximately eightfold. But the present Act itself does not include all the law on the subject. The new Internal Revenue Code ${ }^{11}$ contains, in addition to the provisions of the Revenue Act of 1938, many miscellaneous provisions relating to income tax which were taken from the Revised Statutes or from previously unrepealed portions of prior Revenue Acts. The Revenue Act of

2. 1 American State Papers, Finance, 439.

3. 12 Stat. 432 (1862). The earlier Act of 1861 [12 Sr.1T. 292] never went into effect.

4. Report on the Finances, 1862-63, 70.

5. 16 STAT. 256 (1870).

6. See Magill, Taxable Inconre (1936) 295.

7. 28 Stat. 553 (1894), 31 U. S. C. $\$ 372$ (1934).

8. Pollock v. Farmers' Laan \& Trust Co., 157 U. S. 429, 532 (1895).

9. 38 Stat. 166 (1913), 43 U. S. C. \$ 151 (1934).

10. 52 Stat. 447,31 U. S. C. A. $\$ 752$ (1938).

11. The Code went into effect as absolute law February 10, 1939. It is a compilation of all internal revenue statutes in effect on January 2,1939, and all such statutes are therein expressly repealed. The Revenue Act of 1938 has thus been superseded by the Internal Revenue Code (cited as I. R. C.) although no substantive changes have bzen made in the text of the statute. 
1938 was the thirteenth major effective change in the income tax law since 1913, not including various amendments which were introduced by non-revenue legislation such as the National Industrial Recovery Act. ${ }^{\text {ia }}$ A problem involving one taxable year is very often not to be solved by the same provision that governed the identical situation in the preceding or subsequent taxable year, and it is frequently difficult to determine which set of provisions is applicable to a particular transaction.

This bewildering mass of legislation does not begin to embody all the essential federal income tax law. Court decisions and administrative rulings are quite as important as the statutes. The American Federal Tax Reports, containing all the federal court decisions on federal taxation, now run to nineteen volumes. Since its inception in 1924, the Board of Tax Appeals has issued thirty-eight volumes of published opinions. Moreover, the published rulings of the Treasury Department fill many additional volumes. And the overwhelming majority of cases decided and questions ruled upon involve the income tax.

Necessarily, little of this material is couched in layman's langrage. The taxpayer cannot hope to cope with its vast bulk, its involved language or its infinitude of technicalities. The lawyer or accountant who does not specialize in tax matters often feels himself equally at a loss. It has been rather appropriately stated that "our Federal tax scheme has become one of the law's most fearsome technical toys." 13

By definition, the primary requisite of a good tax law is that it raise revenue. The most technically perfect revenue statute is completely useless if it does not bring money into the Treasury. There are many secondary tests that may be applied in judging a tax, most of them highly controversial, but three upon which all would probably agree are eqtity, certainty and ease of administration. A good tax must distribute its burden fairly. as between taxpayers, in accordance with their relative abilities to bear it. The face of the statute itself should reveal the extent of tax liability in a given transaction without the need for further judicial or administrative interpretation of ambiguous phraseology. In addition, the costs of collection should be kept at a minimum, so as not to absorb an appreciable amount of the revenue raised.

The faculty taxes of colonial times were almost absurdly simple, yet no one would argue for their fairness. A gross receipts tax would do away with most of the vexing and complicated problems which arise under an income tax, but it would not even approximate a reliable measure of a taxpayer's ability to pay. A tax on gross income would be simpler than one on net income, yet it would take no account of such variables

12. 48 Stat. 195 (1933), 15 U. S. C. \$§ 701-2 (1934).

13. Maguire and Zimet, Hobson's Choice and Similar Practices in Federal Taxalion (1935) 48 Harv. L. Rev. 1281, 1333. 
as the expenses incurred in one's trade or business which are now allowed as deductions. Equity and simplicity do not always go hand in hand.

Simplicity may be gained at the sacrifice of certainty. "Ordinary and necessary expenses . . . in carrying on any trade or business," 14 allowed as a deduction, is a simple and non-technical phrase the meaning of which seemingly should be clear to the least sophisticated. But several hundred decisions extending over a period of many years have not yet established with certainty its precise meaning when applied to a given situation. The phrase "earnings or profits,"15 used for ascertaining the taxability of corporate distributions, and the plrase "other property or money," 16 used in determining recognition of gain or loss, are similar in their simplicity, but after the passage of twenty-three and fifteen years respectively, no one can define their meaning with any degree of exactitude.

Nor does simplicity always make for ease of administration. Many of the complexities of the present capital gains and losses provisions could be eliminated by the adoption of the recommendation of the Twentieth Century Fund that "every holder of property . . . be required to report the value of his holdings at the end of the year, and enter the gain or loss - that had accrued since the end of the previous year, or since the date of purchase if he bought within the year." 17 Leaving aside the possible constitutional questions involved in this procedure, the necessity for an annual valuation of the property of every taxpayer would impose an almost insuperable burden on the Bureau of Internal Revenue. In general, it may be said that as greater discretion is vested in the Commissioner by the statute, its text will become somewhat simpler. But the work of the Bureau will thereby become correspondingly heavier, resulting in increased costs of collection and greater delay in the termination of cases.

Nevertheless, it must be conceded that much can be done in the direction of simplifying the administrative provisions of our tax laws. Many of these provisions are antiquated, ${ }^{18}$ dating from the Revised Statutes of 1879. Many bear little or no relation to present conditions and present tax levies. Many have been encrusted with whole series of amendments which render them painfully confusing or utterly meaningless. ${ }^{10}$ Our present mechanism of proceedings and appeals is undoubtedly too cum-

14. I. R. C. $\S 23(\mathrm{a})$.

15. Id. $\$ 115$. The phrase first appeared in the Revenue Act of $1916, \S 2(\mathrm{z}), 39$ STAт. 756, 757 (1916).

16. I. R. C. $\$ 112$ (c) and (d). In its present form the phrase first appeared in the Revenue Act of 1924, §203(d), (e), 43 STAT. 253, 257 (1924).

17. Twentieth Century Fund, Facing the Tax Problesi (1937) 490.

18. The classic example is the section exempting from distraint "one cow, two hogs, five sheep and the wool thereof." I. R. C. \$3691(a) (3).

19. An outstanding example of the existing chaos may be found in the provisions relating to liens for taxes. I. R. C. $\$ \S 3670-36 \$ 0$. 
bersome and is ill-adapted to bear the large amount of highly specialized litigation which it is compelled to carry. ${ }^{20}$

However, when most persons speak of the complexity of the income $\operatorname{tax}$ statute, they are thinking of the complexity of its substantive provisions. It is precisely these provisions which do not lend themselves to simplification. Indeed, any future improvements are likely to be in the direction of more rather than less complexity. A little reflection inescapably leads to the conclusion that simplicity and its attendant consequences almost invariably jeopardize the interests of taxpayers. For it can be asserted almost without qualification that the bulk of the income tax sections, and certainly all of the longer provisions, are for their benefit. The tax could be written with but five essential substantive sections. $^{21}$ All of the rest of the statute is for the relief of the taxpayer. This relief falls into certain general categories, which it may be appropriate to outline briefly.

In the first place, there is an extended list of deductions which may be taken from gross income to compute net income. Indication las already been given as to how this list has expanded from the time of the first federal income tax law. The present Section 23 is about four pages long, consisting of eighteen subsections besides the related subsections of Section 117. Even so it has not yet reached a state in which true net income may be ascertained with complete accuracy. The latest addition was made in order to permit full deduction of losses from the sale of depreciable property used in a trade or business. ${ }^{22}$ Because such property was previously within the definition of a "capital asset," a manufacturer having an obsolescent machine was often tempted to continue to use it or to junk it for its salvage value rather than be permitted only a capital loss if he sold it. Such a sale will now result in a fully deductible loss.

Adequate provision has yet to be made, however, for dediction of previous net operating losses. The 1938 Act took a step in this direction by including a subsection allowing a one-year net operating loss carryover in computing corporate surtaxes. ${ }^{23}$ It might eventually be desirable further to extend these carry-over provisions in the interest of securing more equitable taxation as between corporations with steady incomes and corporations with earnings subject to wide fluctuations.

20. For a thorough discussion of this problem, and a detailed suggestion for a muchneeded solution see Traynor, Administrative and Judicial Procedure for Fedcral Incomc, Estate, and Gift Taxes-a Criticism and a Proposal (1938) 38 CoL. L. Rev. 1393.

21. I. R. C. $\$ \S 11$ and 12 , which set forth the rates of tax applicable to individuals, $\S 22$, which defines gross income; $\$ \$ 41$ and 42 , which set forth the general rules of accounting and methods of allocating receipts.

22. I. R. C. $\$ 117$ (a) (1).

23. Id. $\S 26(\mathrm{c})$. 
A second group of provisions, closely related to the first, grants deductions for income which is used for certain specified purposes and which for reasons of equity is exempted from tax or taxed at a lower effective rate. The deductions for charitable contributions ${ }^{21}$ and amounts paid in to employees' pension trusts ${ }^{25}$ are examples of this group. These deductions are allowed because such contributions partially relieve the Government of the financial burden of contributing for the relief of distress and the security of the aged. There are also the personal exemptions ${ }^{20}$ of $\$ 2,500$ and $\$ 1,000$ allowed to married and single taxpayers respectively, as well as the $\$ 400$ credit for each dependent. ${ }^{2 \pi}$ Such exemptions are based on the theory that the amount of incone that is considered necessary for subsistence should not be taxed.

The dividends-paid credit allowed to corporations for surtax purposes ${ }^{28}$ also belongs in this group, since the greater the percentage of distribution by a corporation, the more taxes are collected from its individual shareholders. Hence the Government can well compensate the corporation for the consequent gain in revenue by correspondingly reducing its tax liability.

A third group of sections also makes special provision for particular kinds of income, in this case because of the source from which the income is derived. Eighty-five per cent of the dividends received by a corporation are exempted from tax, ${ }^{29}$ since otherwise a single distribution might be fully taxed many times before reaching the hands of the individual stockholders for whose ultimate benefit the distribution was made. The credit for earned income ${ }^{30}$ is based on the theory that such income is received subject to the necessity for setting part of it aside as an accumulation of capital to provide for dependents after earning power is reduced or ceases entirely. Income from interest, rents and dividends, on the other hand, is not subject to such necessity since it represents an already accumulated capital. Detailed provisions are also necessary in the case of taxpayers having incomes from possessions of the United States, ${ }^{31}$ and in the case of non-resident aliens deriving a part of their income from this country and a part from abroad. ${ }^{32}$

But the most important and controversial provisions in this group are those dealing with the taxation of capital gains. Iong ago the Supreme Court decided that the term "income" included capital gains."3 It has always been felt that the inclusion of such gains in the statute was justi-
24. Id. $\$ 23(\mathrm{o}),(\mathrm{q})$.
25. Id. $\$ 23(\mathrm{p})$.
26. Id. $\$ 25(\mathrm{~b})(1)$.
27. Id. $\$ 25(\mathrm{~b})(2)$.
28. Id. $\$ 27$.
29. Id. $\S 26(\mathrm{~b})$.
30. Id. $\$ 25(\mathrm{a})(3),(4)$.
31. Id. $\S \S 251$ and 252.

32. Id. $\S \S 119,211-238$.

33. Doyle v. Mitchell Bros. Co., 247 U. S. 179 (1918); Hays v. Gauley Mountain Coal Co., 247 U. S. 189 (1918) ; United States v. Cleveland, C., C. and St. L. Ry. Co., 247 U. S. 195 (1918) ; Merchants' Loan \& Trust Co. v. Smietanka, 255 U. S. 509 (1921). 
fied, since it would not be reasonable to tax the salaried employee and professional man while exempting the dealer and speculator in land or securities. Until 1922 capital gains were taxed in their entirety at the full normal and surtax rates, thus making for relative simplicity of statutory language. Nevertheless, it was soon considered inequitable to tax in one year a gain which might have accrued over a period of several years before realization, where the tax was imposed at graduated rates. Accordingly, all revenue acts starting with the 1921 Act have contained some device whereby a lower effective rate is imposed on long-term capital gains than upon ordinary recurrent income. Until 1934 this was done by giving the individual his choice between the ordinary surtax brackets and a flat rate on capital gains somewhat lower than the highest brackets. ${ }^{34}$ This system was obviously of benefit only to the wealthiest taxpayers. Nor did it sufficiently take account of the length of time during which the gain had accrued. It was found desirable to attempt a more equitable and incidentally more complicated system; a system which would impose a tax intended to approximate the aggregate tax which would have been payable had the gain accrued evenly over the years for which the capital asset was held and had an equal portion of the gain been taxed each year. The 1934 Act therefore abandoned the optional rate and provided that only a percentage of the gain was to be taken into account for tax purposes. $^{35}$ The longer the asset was held, the smaller the percentage of gain taken into account.

This system was thought not to benefit sufficiently wealthy taxpayers for whom the prescribed rates on gains taken into account ran as high as 79 per cent. The 1938 Act therefore combined the schemes of the 1921 and 1934 Acts. Gains upon capital assets held for eighteen months or less are taxed at the full normal and surtax rates. Long-term galins are divided into two categories. ${ }^{36}$ Sixty-six and two-thirds per cent of those upon capital assets held more than eighteen months and not more than twenty-four months are taken into account for tax purposes, and fifty per cent of the gains upon capital assets held more than twenty-four months are similarly taken into account. The gains thus taken into account are included in the gross income of the taxpayer and taxed at the full normal and surtax rates, or they are taxed at a flat rate of thirty per cent, ${ }^{37}$ whichever method results in the lesser tax. This scheme results in subjecting long-term capital gains of those taxpayers whose highest combined normal and surtax bracket is less than thirty per cent to taxation at two-thirds or one-half the rate applicable to other income. The

34. See Revenue Act of 1921, § 206, 42 Stat. 227, 232 (1921) and corresponding sections of the Revenue Act of 1924, 1926, 1928 and 1932.

35. Revenue Act of 1934, $\S 117$ (a), 48 Stat. 680, 714, 76 U. S. C. $\S 101$ (1934).

36. I. R. C. $\S 117$ (b).

37. Id. $\S 117(\mathrm{c})(1)$. 
long-term capital gains of taxpayers whose incomes exceed approximately $\$ 45,000$ are in effect taxed at a flat twenty or fifteen per cent rate.

The $1913 \mathrm{Act}^{38}$ permitted no deduction of capital losses. Further complications have been introduced into subsequent acts by the allowance of such a deduction to a varying extent. The 1938 Act is particularly liberal, and lengthy, in this respect. Short-term losses are deductible only from short-term gains, ${ }^{39}$ but a one-year carry-over of the excess of such losses is permitted, to be applied against the short-term gains of the following year. ${ }^{40}$ Long-term losses taken into account are deductible from gross income or thirty per cent of such losses are credited against the tax, whichever method results in a greater tax..1 This means, in effect, that smaller taxpayers may deduct from gross income two-thirds or one-half of their capital losses accruing over more than eighteen months, while larger taxpayers may reduce their taxes to the extent of fifteen or twenty per cent of such losses.

The capital gains provisions thus far outlined by no means end the matter. In order to stimulate the free flow of capital and in order that normal business transactions shall not be unduly hampered, the Act does not "recognize" a large number of capital gains as income. If Company $A$ transfers all its assets to a newly-formed Company $B$, and the shareholders of Company $A$ receive stock of Company $B$ in exclange for their old equities in Company $A$ which have appreciated in value, the shareholders are in substantially the same position as before the exchange,

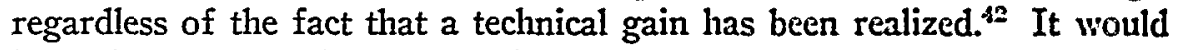
be unfair and burdensome to impose a tax under such circumstances, until the securities received in exchange are later sold. This and similar situations are cared for by the so-called reorganization sections. ${ }^{43}$ Because of the complexity of many of the transactions involved, these provisions are among the longest in the statute and require corresponding adjustments in many other sections.

The 1938 Act provided for the non-recognition of gain upon certain exchanges effected by registered holding companies in obedience to orders of the Securities and Exchange Commission." It also postponed the taxation of gains in excess of accumulated earnings or profits realized upon the liquidation of personal holding companies. ${ }^{43} \mathrm{~A}$ step too was taken towards equalizing the treatment of losses resulting from worth-

38. 38 Stat. 114 (1913), 43 U. S. C. $\$ 152$ (1934).

39. I. R. C. $\S 117(\mathrm{~d})(2)$.

40. Id. $\$ 117(\mathrm{e})$.

41. Id. $\$ 117$ (c) (2).

42. See Rockefeller v. United States, 257 U. S. 176 (1921); Cullinan v. Walker, 262 U. S. 134 (1923); Marr v. United States, 268 U. S. 536 (1925).

43. I. R. C. $\S \S 111,112,113$.

44. Id. Supplement $\mathrm{R}$, $\S 371-373$.

45. Id. $\$ 112(\mathrm{~b})$. 
lessness and losses due to sales of property which had depreciated in value. ${ }^{46}$ A loss upon a security which had become worthless was previ* ously deductible in full, ${ }^{47}$ whereas a loss upon the sale of a security which had not become totally worthless was subject to the capital loss provisions. This often resulted in the retention of depreciating securities until they became of no value, in order to secure a full deduction. To remedy this situation, a loss due to a security becoming worthless is now considered a capital loss.

The fourth group of relief provisions assures favored tax treatment to a wide variety of special classes of taxpayers. Some of this favored treatment is eminently justifiable. For instance, the unfairness that would result from applying the individual surtax rates to the net incomes of corporations is obvious to all. Even further relief is warranted in the case of the very small corporation. Presumably it is young and growing, it does not have ready access to the capital market and may need to retain a large proportion of its earnings. Accordingly, corporations with incomes not in excess of $\$ 25,000$ are taxed at an effective rate ${ }^{48}$ lower than that applicable to the minority of corporations, ${ }^{40}$ and they are not subject to the two and one-half per cent undistributed profits tax differential.

Still greater concessions are made to trusts and partnerships. In the case of a corporation, a tax is imposed upon the receipt of income by the corporation and another tax is later imposed on the beneficial owners upon receipt by them of the same income in the form of dividends. ${ }^{50} \mathrm{~A}$ trust, on the other hand, is taxed separately only on that part of its income which is not currently distributed to the beneficiaries. ${ }^{51}$ A partnership is not taxed at all. The distributive shares of its income are included in the returns of the partner, whether distributed or not. ${ }^{62}$ In this connection note the further relief, and the further complication, contained in the Revenue Act of 1938. Obviously, in order to ascertain the distributive shares of the partners, the net income of the partnership must be separately computed. ${ }^{53}$ Under prior acts, the result of stuch computation was that partnership capital losses were not available to offset the capital gains of the individual partners. And if a partner had sustained a net capital loss, it could not be deducted from his share of the net capital gain of the partnership. In order to remedy this situation, the 1938 Act provided that the ordinary income and the capital gains and losses of a partnership are to be segregated. ${ }^{54}$ A partner's distributive share of the ordinary income is to be added to his individual income, and

46. $I d . \S 23(\mathrm{k})(2)$.

48. I. R. C. $\S 14$.

50. Id. $\S 115$.

52. Id. $\$ \$ 181,182$.

54. Id. $\S 183(\mathrm{~b})$.
47. Regulations 94, Art. 23(k) 4.

49. Id. $\$ 13(\mathrm{a})$.

51. Id. $\S 162(\mathrm{~b})$.

53. Id. $\S 183(\mathrm{a})$. 
his distributive share of the net capital gain or loss is to be separately included in his individual net capital gain or loss computation.

There is also some justification for the favored treatment granted by the Statute to insurance companies, ${ }^{55}$ and there is ample ground for the exemption accorded to charitable ${ }^{5 B}$ and civic organizations, ${ }^{67}$ farmers' cooperatives, ${ }^{58}$ voluntary employees' benefit associations ${ }^{59}$ and employees' pension trusts, ${ }^{60}$ certain quasi-municipal utilities, ${ }^{\text {ol }}$ and a host of other organizations, each of which may require a separate subsection in the Act or a long series of additional sections.

On the other hand, numerous special deductions and exemptions which have insinuated themselves into the Statute are completely indefensible from the standpoint of tax equity. There is no apparent reason for the complete exemption of building and loan associations ${ }^{62}$ and for the almost complete exemption of China Trade Act corporations. ${ }^{63}$ The present depletion provisions ${ }^{64}$ result in a hidden subsidy to the oil and mining industries. The exclusion from taxation as dividends of distributions made from earnings or profits accumulated prior to March $1,1913^{\mathrm{cs}}$ results in the shareholders of a few corporations securing treatment more favorable than that accorded the generality of shareholders. Despite increasing sentiment for a legislative change, ${ }^{60}$ the notorious exemption of interest on state and municipal securities is still a part of the Statute. ${ }^{.7}$ Once provisions of this type have wormed their way into the Statute, it is almost impossible to extricate them, supported as they are by the clamor of the special interests for whose benefit they were enacted. However, further complexity along these lines can be avoided by resisting any additional special treatment for special interests. The burden of every tax favor granted by Congress falls upon the average taxpayer. Every revenue loss occasioned by a concession to an isolated class must necessarily be paid for by the tax-paying public.

The foregoing discussion logically leads to the next group of provisions - a group which is responsible for the most detailed and involved portions of the income tax law - namely, those sections of the Act which
55. Id. $\S \S 201-207$.
56. Id. $\S 101(6)$.
57. Id. $\$ 101(8)$.
58. Id. $\S 101$ (12), (13).
59. Id. $\$ 101(16)$.
60. Id. $\S 165$.
61. Id. $\$ 116(\mathrm{~d}),(\mathrm{e})$.
62. Id. $\$ 101(4)$.
63. Id. $\S \S 261-265$.
64. Id. $\S \S 23(\mathrm{~m}), 114(\mathrm{~b})$.
65. Id. $\S 115(\mathrm{~b})$.

66. In two messages to Congress, dated April 25, 1938, and January 19, 1939, the President recommended the enactment of legislation imposing federal income tax upon interest on future issues of state and municipal obligations and upon salaries received in the future by state and municipal employees. He also recommended that the states be given power to tax the interest upon future issues of federal obligations and the salaries received in the future by federal employees. Those of his recommendations which relate to salaries are embodied in the Public Salary Tax Act of 1939, effective April 12, 1939.

67. I. R. C. $\$ 22(b)(4)$. 
are designed to prevent avoidance of taxes. At first blush these sections would scarcely seem to be relief provisions. That the characterization is apt, however, will appear after a moment's reflection. If certain large taxpayers escape their proportionate share of the tax burden, the burden on the taxpaying public is correspondingly increased. Every provision which brings in fugitive tax dollars relieves the average taxpayer of a part of that burden. For the very reason that these sections deal with a class of taxpayers which, by definition, is prone to take advantage of every discoverable loophole in the law, it is particularly important that they be made evasion-proof. Every conceivable situation intended to be covered must in some way be brought within the scope of the language of the Statute; otherwise the provisions will be mere sound and ftrry. To close the many loopholes which the taxpayer's ingenuity may uncover often requires an abundance of verbiage. Moreover, the devices which are used to avoid taxes are often very intricate and only intricate provisions can deal with them adequately. Therefore there are about fourteen pages devoted to personal holding companies, domestic ${ }^{68}$ and foreign, ${ }^{00}$ two pages to corporations improperly accumulating surplus, ${ }^{70}$ a long section dealing with losses from wash sales, ${ }^{71}$ several sections devoted to the problem of revocable trusts ${ }^{72}$ and many others devoted to equally complicated devices. These provisions do not make easy reading, but it must be remembered that they are not aimed at the unsophisticated.

Loophole plugging is not, however, confined to certain isolated portions of the Statute. It is almost axiomatic that nearly every general relief provision granted by Congress was taken advantage of by some taxpayers. It would be simple to prevent this by abrogating the relief provisions altogether, but the more equitable method which has generally been adopted is to restrict their application. Hence, many of the provisions which grant relief are hedged about by innumerable qualifications. One of the earliest examples relates to the deduction of interest. It was found that some taxpayers were borrowing money to invest in tax-exempt securities. They paid no tax upon the income from the investment, while decreasing their taxable income by deducting the interest paid to make the investment. Instead of denying to all taxpayers the privilege of deducting interest from gross income, Congress therelpon added a few words to the Act which stopped this particular practice while continuing to make the deduction available for other purposes. ${ }^{73}$ The privilege of a limited deduction of losses was not taken away when it was found that some taxpayers created fictitious losses by selling depreciated securities one day and buying them back the next, or by

68. Id. $\S \S 500-511$.

70. Id. $\S 102$.

72. Id. $\$ \S 166,167$.
69. Id. Supplement $\mathrm{P}, \S \S 331-340$.

71. Id. $\$ 118$.

73. Id. $\S 23(\mathrm{~b})$. 
fictitious sales to specially created trusts or close relatives. "2 Particular provisions were written into the Act to cover these situations. The trust device has been employed in a variety of ways by the ingenious taxavoider but still not all trust income is taxed to the grantor. Instead, only the income from those types of trusts which can most easily be used for the avoidance of taxes ${ }^{75}$ is so taxed.

Another favorite method by which the Statute was used to secure an unfair advantage appeared when a taxpayer claimed a deduction which he had already taken in an earlier year with respect to which the assertion of a deficiency was barred by the Statute of Limitations. If the later year was then finally determined by the courts to be the proper one in which to take the deductions, the taxpayer congratulated himself upon having secured a double deduction by maintaining an inconsistent position with respect to two different taxable years. The variations of this device were infinite, and it must be conceded that the Government had a few in its own repertory. ${ }^{70}$ Section 820 of the 1938 Act attempted to remedy the resulting chaos. ${ }^{77}$ If, in certain specified situations, it is finally determined that a certain item is to be included in or deducted from gross income in any taxable year, and such item was also included or deducted in a previous year, an adjustment will be made with respect to the tax for the previous year despite the fact that such adjustment would otherwise be barred by the Statute of Limitations. The Section is long and very complicated, even though it does not cover every situation of this type. But it was a monumental task to remedy this defect in the tax laws, while preserving, at the same time, the principle that the Statute of Limitations should insure a decent burial of stale claims. Much of the extensive friction and litigation which is concerned solely with allocating items to the proper year should be eliminated by these new provisions. Any perfection of Section $\$ 20$ will probably require its further expansion.

Only a brief outline has been given of the many varied and complex transactions which the provisions of the income tax law must encompass. There are a multitude of other situations which have not even been considered. It is a commonplace that modern economic life is extraordinarily complex, but the implications of this fact are not sufficiently realized in the field of tax legislation. We can and should modify our administrative procedure; we can and should eliminate much of the present overlapping of state and federal taxation. But since we have a revenue law which

74. Id. \$§ 118, 24(b).

75. Id. $\S \S 166,167$.

76. For a picture of the situation before the enactment of Section $\$ 20$, now Section 3801 of the Internal Revenue Code, see Maguire and Zimet, Hobson's Choice and Similar Practices in Federal Taxation (1935) 48 HaRv. L. Rev. 1281.

77. For an excellent and exhaustive analysis of the section, see diaguire. Surrey and Traynor, Section 820 of the Recente Act of 1935 (1939) 4S YALE L. J. 509. 
measures taxable capacity by so complex a standard as net income, that law cannot and should not be simple in structure. The elimination of any of the more important relief provisions would produce gross inecquity and great hardship for many taxpayers; this would seem to be too high a price to pay for a statute readily comprehensible to all. As Sir Josiah Stamp, the eminent British authority on revenue matters, has said:

"It may not be out of place . . . to register a deliberate opinion that the clamour for a simple Income Tax, which he who runs may read, is an absurd one. In many particulars, not always the most important, the existing chaos of rules can indeed be greatly simplified, but if the tax is to be so highly subjective as to reflect every slight difference in ability, on grounds of aggregate amount of income, marital condition, family responsibility, character of income, elements of capital, origin and source of profits, and all the other differentiae which are now urged, then, unless it is to be reduced to the status of a voluntary offering, it must be a complicated system.

"The United States had a full opportunity to get a simple system, having no previous commitments, and the great advantage of a prolonged study of other nations. Within a few months there were widespread complaints that the law and system were "irritatingly incomprehensible.' In 1915 I was prompted to write, 'There is the usual failure to see that modern life and modern commerce are so complex and diversified that to expect a tax form which shall read like a pill advertisement on the railway, and yet close down upon every case, is asking for the moon." "78

This statement was made before the Royal Commission on the Income Tax in 1920. Thus the campaign for simplification is scarcely new. It is the perennial cry of the bewildered taxpayer. From 1851 to 1928 eight special commissions have been appointed in England to inquire into the practicability of simplification. In this country we have heard strident complaints about the complexity of the income tax almost since its inception. By 1927 these complaints had reached a crescendo, and the Joint Committee on Internal Revenue Taxation carefully consiclered how the income tax could best be simplified. Its report resulted in a much needed rearrangement of the law in the 1928 act, $^{70}$ so that the ordinary taxpayer was thenceforth able to find the material most likely to affect his return collected at the beginning of the Act. Some minor administrative changes were also made, but on the subject of a law simple in its substantive provisions the Committee reached the following conclusion:

"It must be recognized that while a degree of simplification is possible, a simple income tax for complex business is not. The task

78. Testimony of Dr. J. C. Stamp before the British Royal Commission on the Income Tax, August 1, 1919. Cmd. 615, Minutes of Evidence, I, $\Uparrow 9481$ (1920).

79. 45 Stat. 791 (1928). 
is to simplify the law and the administration for all taxpayers so far as possible, without causing real hardship to those with complex sources of income and varied business enterprises who can not be taxed justly under a simple, elementary law." 80

In view of the almost unanimous opinion of taxpayers, lawyers, accountants and many legislators that the income tax law is written in an incomprehensible technical jargon, there is an astonishing dearth of specific suggestions as to just how the law could be simplified. The usual advocate of simplicity, when pressed for concrete proposals, frequently wanders off into airy generalities, remarking that the actual details must, of course, be worked out by a technical staff. Occasionally, however, he is so incensed by the obfuscations of a particular provision that he asserts that he could render the same passage into a brand of English positively lyric in its simplicity. When asked to do so, the product is almost invariably a short simple sentence which is either meaningless or reaches a result quite different from that which was intended.

These phenomena are apparently not confined to this side of the Atlantic. In the report of the Colwyn Commission in England there appears the following paragraph, rather admirable in its restraint:

"We have been guided also in our deliberations by a desire that the machinery of taxation should not be made more complicated, but that it should be simplified at any point where simplification is consistent with justice and common sense. A plea for simplicity was made by a great number of witnesses, some of them experts in dealing with Income Tax matters on behalf of the public, but we found their suggestions generally vague and indefinite. They were either unable to give us concrete or definite proposals, or, where they did make proposals, we found that to adopt them would be to do injustice to taxpayers whose peculiar circumstances would not have been recognized, or to expose the Revenue unnecessarily to the risk: of loss. We have formed the opinion that in Income Tax matters simplicity is not the sole object to be aimed at, and that the price that would have to be paid for a simple Income Tax could not be justified." 81

Any provision of a tax law sounds simple when it is stated in general terms. This is because the results intended to be reached usually are fairly simple. Complications ensue only when there is an attempt to effect these results by statutory language which will apply with certainty in all cases. For example, the language of the surtax on undistributed

80. 1 Report of the Jonnt Consmitee on Internal Revenue Taxatio: (1927) 5.

81. Report of the Royal Conarission on the Inconre Tax (1920) Cmd. 615, I649. A good example is to be found in the testimony of MIr. A. Mr. Bremner, Mlinutes of Evidence, Part II, \15,491. He had complained about obscurity and complexity. When asked whether he had formulated a satisfactory definition of "Profits and Gains," he replied, "No, the Long Vacation was not long enough to enable me to do that." 
profits contained in the 1936 Act $^{82}$ was generally hailed as a stpertechnical monstrosity. When the corporate tax plan of the 1938 Act was announced, newspaper editorials appeared in praise of its clarity and simplicity. The corporate normal tax and the surtax on undistributed profits were to be abolished. In their stead corporations with net incomes not in excess of $\$ 25,000$ were to be taxed at a progressive rate ranging from twelve and one-half to sixteen per cent. ${ }^{83}$ Corporations with incomes exceeding $\$ 25,000$ were to be taxed at a flat rate of nineteen per cent, reduced by a credit of two and one-half per cent of the amount of dividends paid. ${ }^{84}$ This was indeed comprehensible to anyone laving a background of grammar school arithmetic. But this paragon of simplicity required more than six pages when put into statutory language. Provision had to be made to prevent a corporation with an income of $\$ 25,001$ from incurring a tax liability over $\$ 1,000$ greater than that of a corporation with an income of $\$ 25,000 .^{85}$ A provision had to be made to prevent a corporation from securing a dividends-paid credit in excess of its adjusted net income. ${ }^{86}$ Provisions were inserted for the relief of corporations in special circumstances ${ }^{87}$ and of corporations whose shareholders were willing to include their ratable shares of the corporate income in their individual returns even though such income was undistributed. $^{88}$ A score of other problems had to be solved, each of which required some expansion of the language of the relevant sections, with the result, sad to relate, that one of these sections, dealing with the dividend carry-over, ${ }^{80}$ has been sarcastically quoted both on the floor of the House ${ }^{00}$ and on the editorial page of the New York Times ${ }^{01}$ as an example of "pure limpid English." However, it is probably impossible to draft a less complicated sounding provision which would contain the really simple rule set forth in that section.

There are nevertheless several suggestions for simplifying the income tax which do not involve removing either relief provisions or the safeguards with which those provisions must necessarily be surrounded. It may be appropriate to make a few observations upon the four plans most frequently and plausibly advocated:

1. The first of these involves the frequent complaint that taxable income does not in all instances correspond to accounting income. It is asserted that if the two disparate income concepts could be made to coincide, a much simpler statute would result. This argument, of course, assumes the infallibility of accounting methods in clearly reflecting net

82. ReVenue Act of 1936, §§ 14, 26 and 27, 49 Stat. 1648, 1655, 1664, 1665 (1936).

83. I. R. C. \&14(c).

84. Id. $\$ 13(\mathrm{c})$.

85. Id. $\S 13(\mathrm{~d})$.

87. Id. $\S \S 14,26$ (c) (1), 27 (a) (4).

89. Id. $\$ 27$ (c).

86. Id. $\S \S 26(\mathrm{~b}), 27$ (b) (1).

88. Id. $\$ 28$.

91. N. Y. Times, March 5, 1938, p. 16, col. 1.

90. 83 Cong. Rec. 3737 (1938). 
income, whereas as a matter of fact accounting technique, like legal technique, involves a constant use of fictions. Even granting the premise, the law must in some measure formulate its own rules of accounting, since different types of taxpayers may use widely varied accounting methods. In any case, because income must still be determined upon an annual basis for the purposes of taxation, ${ }^{02}$ it is necessary that definite rules be laid down fixing the proper year in which various items arise. These rules are bound to differ somewhat from the ordinary accounting methods which are more at liberty to take prior and future years into consideration. The disparity could largely be cured by a statute which measured income by a period longer than a year, but such a cure would be in the direction of greater and not less complexity.

2. A second plan advocates some sort of optional tax on gross income. The taxpayer might elect to pay a lower rate of tax upon his gross income than the prevailing rate upon net income. In another form, it is suggested that he might, at his election, take a blanket deduction of a fixed percentage of his gross income, say ten per cent, in lieu of the numerous specified deductions allowed by the present law. Aside from the revenue loss inherent in this proposal, its basic difficulty lies, surprisingly enough, in its complexity. It would mean putting additional sections into the Act. It would also mean that the taxpayer would still have to compute his net income in order to decide whether or not it was to his advantage to exercise the option. It is hard to envision the spectacle of taxpayers en masse paying the optional tax merely because they were too lazy to determine whether the more complicated alternative resulted in a lesser liability.

3. The third and most widely advocated suggestion involves a new departure in legislative drafting of the income tax. The contention is made that it is a hopeless task to write a statute which will include every detail and cover every conceivable case. Such attempts, it is asserted, result in making confusion worse confounded, and in opening up new loopholes as fast as the old ones are closed. The alternative is said to be a statute setting forth merely the important general rules, the application of those rules being left to the courts.

Without doubt such a drafting scheme would result in a statute simply and clearly stated. But it would certainly not result in a simple tax law..$^{93}$ The same details would have to be worked out, and the same long series of specific applications determined. But instead of being largely collected between the covers of one Act of Congress, they would be discoverable only by thumbing through an infinite number of scattered

92. I. R. C. $\S 41$.

93. See Alvord, Possibilities of Future Tax Law Simplification (1928) 6 NAT. Ixcosie TAX MAag. 365 for an excellent analysis of some of the difficulties inherent in this proposal. 
court decisions. It is already irritating enough to have to consult innumerable cases, opinions and rulings in order to determine some olscure point in the law, and such irritations necessarily would be many times multiplied. The judicial mill is already choked with tax cases; the problem is to lighten the load and not to increase it. Increased litigation means increased costs of collection, which in turn mean higher taxes and also greater expense to the taxpayer. In effect, it means a subsidy for the tax attorneys.

Furthermore, increased litigation results in greater delays and uncertainties. The tax liabilities of the majority of taxpayers can still be ascertained by referring to the Revenue Acts, even though it may often take some concentrated effort to do so. Under a statute written exclusively in general terms, no tax liability could be determined until the courts had passed upon the specific question involved. This would ustally take several years. And when we speak of the courts, we actually mean the Supreme Court. Few tax questions are ever put at rest until they have been interred in the United States Supreme Court Reports, except in the rare instances in which every Circuit Court of Appeals and the Court of Claims are in accord and no writ of certiorari is granted. In the meantime, the issue is usually obscured by a mass of conflicting decisions.

Nor is the Supreme Court itself invariably prompt to illuminate every dark corner of an obscure problem. Remarkably enough, the general provisions of the statutes give the most trouble. Some of the undefined general terms in the Revenue Act which have occasioned the most uncertainty have already been enumerated. The last judicial words on "ordinary and necessary expenses," 04 "other property or money," ${ }^{05}$ and "earnings or profits," ${ }^{96}$ have yet to be spoken. It is nineteen years since the famous case of Eisner v. Macomber ${ }^{07}$ decided that a common stock dividend paid to common stockholders was not income. But many of the problems connected with stock dividends are still with us, and the recent decisions ${ }^{08}$ on the subject have only produced further confusion. It is twenty-six years since the passage of the Sixteenth Amendment, yet in certain important respects its construction is still in doubt, and this despite the fact that, as Mr. Justice Holmes pointed out, its "known purpose was to get rid of nice questions." ${ }^{00}$ We have had a Constitution for more than 150 years, and yet its application to many recurring legis lative problems is still in doubt and subject to occasional reversal of opinion. Again it is the general provisions which occasion the most

94. I. R. C. $\S 23(\mathrm{a})$.

96. Id. $\S 115$.

98. Koshland v. Helvering, 298 U. S. 441 (1936); Helvering v. Gowran, 302 U. S. 238 (1937) ; Helvering v. Pfeiffer, 302 U. S. 247 (1937).

99. In his dissenting opinion in Eisner v. Macomber, 252 U. S. 189, 219 (1920). 
dispute. The prospect of having a specific tax question finally settled during the old age of the taxpayer's great-great-grandchildren is not a happy one.

A recent article in the Columbia Law Reciem, ${ }^{100}$ attacked the Revenue Act of 1937 on the ground that its provisions were too detailed and that by their very explicitness they excluded reasonable latitude in determining which personal holding companies were being used primarily for the avoidance of individual surtaxes. The Act, of course, defines personal holding companies ${ }^{101}$ and personal holding company income ${ }^{102}$ in great detail. The article concedes that the fifty per cent stock ownership requirement and the five individual group requirement will have to be retained. But it suggests that the statutory test should be, not whether fifty per cent or more of the stock is owned, directly or indirectly, by not more than five individuals, but rather whether such amount of stock be owned or controlled, directly or indirectly, by not more than five individuals. This change, it is asserted, will make possible the removal of the long and complicated sections dealing with ownership by members of a family or partnership, or through corporations, estates, trusts and option agreements. ${ }^{103}$ Similarly, it is suggested that the lengthy provisions dealing with disallowed losses upon sales between members of a family, partnership or trust ${ }^{104}$ could be done away with by a short statement that "the loss upon the sale or other disposition of property shall not be recognized where the seller retains control, directly or indirectly, over the property which is the subject-matter of the sale."

Such amendments would very much simplify the appearance of the Act. Unfortunately, the word "control" is both vague and indefinite. Its meaning, as here applied, could be ascertained only after many administrative rulings had run the gamut of the courts. Even after a body of decisions had been built up covering some disputed points, few holding companies would ever be certain, from year to year, whether they were liable for the surtax. Moreover, the word "control" has many subjective implications which are impossible to determine accurately in a specific case. Does a man have more effective control of stock owned by his grandson or of stock owned by his nephew? Does he control more effectively the stock of a mother-in-law, whose affairs he manages, or the stock of a daughter dominated by a husband who dislikes him? This proposal would clutter up the dockets with just such absurdities. No provisions of our revenue laws are more productive of irritation than those which cause taxability to depend upon subjective tests. A tax lawyer would hate to be called upon to define accurately stock "controlled" by an individual, just as he would hate to have to define with precision a

100. Angell, Tax Evasion and Tax Avoidance (1938) 38 CoL L. Rev. 80.

101. I. R. C. \$501.

102. Id. § 502 .

103. Id. $\S 503$.

104. Id. $\S 24(\mathrm{~b})$. 
gift made in contemplation of death ${ }^{105}$ or a corporation formed or availed of for the purpose of preventing the imposition of the surtax upon its shareholders. ${ }^{106}$

4. The final suggestion for simplification to be mentioned is one proposing the enactment of a statute in general terms, leaving the details to be filled in by administrative regulation. ${ }^{107}$ Unless the Commissioner's rulings were rendered immune from judicial review, this suggestion would have the same result as a general statute interpreted by the courts, so it is open to the same objections and there is little additional to be said of it. The Bureau of Internal Revenue is already overburdened; to force it to write as well as to administer the revenue law would make for much inefficiency and delay. Its personnel is constantly changing, with the result that it is difficult to secure uniform consistency in its rulings. The 1938 Act conferred upon it a discretionary authority to enter into closing agreements with respect to taxable years not yet terminated. ${ }^{108}$ This and certain other additional burdens are all that it can adequately handle at the present time. Merely because simplification of the substantive portions of the income tax law is, in general, neither feasible nor desirable, no inference is intended here that a real improvement of the Statute is impracticable. Such improvements as are now contemplated, or that may be contemplated in the future, are, however, likely to increase the complexity of the Act rather than to simplify it.

Much remains to be done towards securing greater equity and greater certainty. For example, it might be desirable to formulate a satisfactory definition of "earnings or profits," in order that individuals may be better able to ascertain whether the distributions they receive are taxable 100 and in order that corporations may be enabled to know in advance whether the distributions they make will secure them a dividends-paid credit. ${ }^{110}$ Much of the existing confusion with respect to the proper treatment of assumptions of indebtedness in corporate reorganizations needs to be eliminated, ${ }^{111}$ as does the confusion with respect to constitutionally taxable

105. Id. $\$ 811(\mathrm{c})$.

106. Id. \& 102. See (1939) 48 Y ALE I. J. 1105.

107. For a more detailed discussion of the implications of this proposal, sce Green, Simplification and the Federal Tax on Earned Incomes (1928) 6 NAT. Incone TAx Mag. 47.

108. I. R. C. $\S 3760$.

109. Id. §115(a).

110. Id. $\S \S 27$ (b) (1), 335, 504(a).

111. See United States v. Hendler, 303 U. S. 564 (1938). The problem resolves itself into two parts: (1) whether, and to what extent, gain should be recognized to the transferor corporation in a reorganization exchange because of the mere fact that such corporation has transferred its liabilities along with its assets; and (2) whether the assumption should remove the transaction from the benefits of the reorganization sections altogether if such transaction takes the form of an exchange of substantially all the property or 80 per cent of the voting stock of the transferor for voting stock of the transferee. See I. R. C. $\S 112$ (g) (1) (B). 
stock dividends distributed prior to 1936.112 All this will add to the bull: of the Statute. It would be desirable to remedy the inequity that exists as between married taxpayers in the eight community property states and married taxpayers in the rest of the country. In forty states and the District of Columbia, a husband is taxed upon all his earnings. In the remaining eight states, because of their local property laws, the earnings of the husband may be taxed one-half to the wife and one-half to the husband, ${ }^{113}$ thus often materially reducing their combined surtax liability. Some provision will eventually have to be worked out to remedy this situation, but it will result in greater complexity. It might be desirable to expand the present deduction of expenses incidental to a trade or business to include all expenses properly and reasonably incurred in the collection or production of all types of income. This would not be an easy provision to write in a few short sentences. The tax burden needs to be equalized as between corporations with normally steady incomes and corporations with violently fluctuating earnings. But greater liberality in the allowance of net operating losses will still further amplify the Revenue Act. These are only a few of the proposals which are worthy of present consideration.

In the last analysis, the bewilderment of the average small taxpayer whose income is derived from wages and salaries has been somewhat exaggerated. Nearly ninety per cent of all individual taxpayers filing

112. Until the decision in Koshland v. Helvering, 298 U. S. 441 (1936), it had universally been supposed that, in the case of a stock dividend, the basis of the stods upon which the dividend was declared was to be allocated between the old stock and the stod: distributed. See U. S. Treas. Reg. 86, Art. 22(a)(8) and corresponding articles of prior Regulations. The Koshland case involved the distribution to stockholders of a class of stock different from that which they held and decided that, upon a subsequent sale of the old stock, the basis of such stock should be its full cost. Helvering v. Gowran, 302 U. S. 238 (1937), relating to a comparable situation, decided that the basis of the new stock should be zero. It is possible that a taxpayer who, prior to 1936, had sold his new stock and had computed gain or loss upon an allocated basis, may now claim that, under the Koshland case, his old stock should have a full cost basis. If the assertion of a deficiency with respect to the earlier year is now barred by the Statute of Limitations, he may recover tax-free more than his cost. Conversely, a taxpayer who had previously sold his old stock and computed gain or loss upon an alloated basis may be denied recovery of his full cost tax-free because the new stock should have a zero basis.

The same problem does not arise after 1935, since the 1936 Act taxed os a diridered all distributions which might constitutionally be so taxed. Revexue Acr of 1936, $\S 115(f)$. This provision has been continued in subsequent Acts. Inasmuch as the Koshland and Gowran cases held distributions in a different class of stock to be constitutionally tamable as dividends, such a distribution is now taxable upon receipt to the extent of its full market value. The old stock retains its full cost basis and the new stock acquires a basis in the amount of market value at the time of distribution.

113. Poe v. Seaborn, 282 U. S. 101 (1930); Goodell v. Koch, 282 U. S. 118 (1930); Hopkins v. Bacon, 282 U. S. 122 (1930); Bender v. Pfaff, 282 U. S. 127 (1930); United States v. Malcolm, 282 U. S. 792 (1931). 
returns for 1935 reported incomes of less than $\$ 5,000.114$ Their tax law consists solely of the return. Most of them have never seen the involved Revenue Act or the equally involved Regulations. The form of return which they file is now very simple. ${ }^{115}$ And while the instructions accompanying it can scarcely be cited as outstanding examples of a simple prose style, they are not as incomprehensible to the average person as are other legally-phrased documents with which he is periodically confronted, such as mortgages, insurance policies and conditional sales contracts. On the other hand, no matter how relatively simple the income tax could be made, the larger taxpayer would be compelled to seek professional advice with respect to his more complicated transactions. Lawyers no longer regard tax law as an esoteric technique to be employed only by the spew cialists. They have come to realize that they must have at least a working knowledge of a field which so vitally affects the interests of their clients. Indispensable as it is to an adequate knowledge of many other branches of the law, they are discovering that its mysteries are not as unfathomable as they had once supposed. Simplicity is not a goal per se, and it is definitely undesirable when it conflicts with the major objectives of a good tax system. Because they interpret the law to the taxpaying public, the responsibility of urging the proper kind of tax reform rests upon the members of the bar. They can do much by refusing to press for special favors to special interests, thereby preventing a few individuals from profiting at the expense of the general public. They can do even more by opposing the elimination of material portions of the revenue laws when such elimination is proposed in the name of simplification alone.

114. Statistics of Income for 1935.

115. Form $1040 \mathrm{~A}$, applicable to most individual taxpayers having incomes less than $\$ 5,000$, was materially simplified in 1937 . Form $1140 \mathrm{~A}$, applicable to the almost $90 \mathrm{per}$ cent of corporations whose incomes do not exceed $\$ 25,000$, has also been greatly simplified. 


\section{THE YALE LAW JOURNAL}

EDITORIAI BOARD

LANGDON VAN NORnEN

Editor-in-Chief

MacDonato Dexing

Lours T. STONE, JR.

Fraste A. Hutso::, JR.

Comment Editors

Geozes J. Yudist

Note Edilors

Irving Parker

Article and Book Reziew Editor

Rowley BIALLA

JoNATHAN B. BINGHASF

Kent H. BRown

RALPH S. BROWN, JR.

Paut S. Cleaveland

LIOYd N. CutLer

Newton H. DeBardeleben

KenNeTh P. DIILON

HERBERT A. Fierst

RICHARD I. GALLAND

\begin{abstract}
MARY T. GOODE
LouIs W. GoodkIND

Lewis Greensaudr

ARTHUR GrostaN

ROY C. HABEREERN, JR.

Jazres G. JoHason, JR.

PETER H. KaATINER

JosepH W. KEENA

EDWARD H. KENYON

JAMTES B. LIBERIMAN
\end{abstract}

\author{
Jon: W. Nienos \\ Ronent A. Nitscrine \\ Currono L. Portars \\ Dastrer B. Posiers \\ Jorn: R. RAIE: \\ Sw:ZE: AL. Scumemen \\ Lloyd S. SREDEreEs \\ WALTER S. SunNEY \\ EARI J. WOFSEY \\ Jesosere S. Zunsow
}

Subscription price $\$ 4.50$ per year

So cents por number

Canadian subscription price $\$ 5.00$ per year; Foreign, $\$ 5.25$ per ycar

Yale Lawe Journal Company, Inc., Box 40IA, Yale Station, New Haven, Conn.

By the appointments of Dean Charles E. Clark to the Circuit Court of Appeals for the Second Circuit and of Mr. Justice William O. Douglas to the Supreme Court, the Yale School of Law has been deprived of two of the most distinguished members of its staff. The debt owed to them by the Jounus is manifest in many of its pages. Their contributions to the growth of the School and the progress of legal education are permanent monuments to their scholarship and service. For ten years Judge Clark has served the School as Deari and has guided it during a period of notable growth in which Mr. Justice Douglas was a powerful factor. We extend to them both warm wishes for happy judicial careers. 